\title{
PENGARUH INFLASI, UKURAN, DAN UMUR TERHADAP KINERJA REKSA DANA SAHAM DI INDONESIA
}

\author{
Sendi Christiandi ${ }^{1}$, Fredella Colline ${ }^{2}$ \\ ${ }^{1}$ Program Studi S1 Manajemen, Fakultas Ekonomi dan Bisnis, Universitas Kristen Krida Wacana, Jakarta \\ ${ }^{2}$ Fakultas Ekonomi dan Bisnis Universitas Kristen Krida Wacana, Jakarta \\ ${ }^{1}$ sendi.2017em094@ civitas.ukrida.ac.id \\ 2 fredella.colline@ukrida.ac.id
}

\begin{abstract}
ABSTRAK
Perkembangan investasi di pasar modal sudah berkembang mengikuti perubahan industri terutama berinvestasi pada reksa dana saham. Penelitian ini bertujuan untuk mengetahui pengaruh variabel inflasi, ukuran reksa dana saham, dan umur reksa dana saham terhadap variabel kinerja reksa dana saham. Pengumpulan sampel menggunakan teknik purposive sampling untuk reksa dana saham yang terdaftar di Otoritas Jasa Keuangan periode 2010-2019. Berdasarkan kriteria sampling, diperoleh sampel sebanyak 37 reksa dana saham. Data sampel dianalisis dengan menggunakan analisis regresi linier berganda. Berdasarkan hasil penelitian disimpulkan bahwa inflasi berpengaruh signifikan terhadap kinerja reksa dana. Ukuran reksa dana dan umur reksa dana tidak mempengaruhi kinerja reksa dana saham. Melihat dari hasil penelitian tersebut maka manajer investasi sebagai pihak yang dipercaya oleh para investor dalam mengelola dana investasinya perlu memperhatikan inflasi dalam mengelola aset secara tepat. Sebagai investor perlu memperhatikan kebijakan investasi dalam fund fact sheet, prospectus, dan strategi masing-masing reksa dana saham yang ingin diinvestasikan agar dapat mengambil keputusan yang tepat.
\end{abstract}

Kata Kunci: Kinerja Reksa Dana Saham, Inflasi, Ukuran Reksa Dana Saham, Umur Reksa Dana Saham

\begin{abstract}
The development of investment in the capital market has developed in line with industry changes, especially investments in equity funds. This research aims to determine the effect of the inflation variable, the size of the equity fund, and the maturity of the equity fund on the performance variable of the equity fund. The sample was conducted using a purposive sampling technique for equity funds registered in the Financial Services Authority of Indonesia (OJK) for the 2010-2019 period. Based on the sampling criteria, a sample of 37 equity funds was obtained. The sample were analyzed using multiple linear regression analysis. Based on the results, it was concluded that inflation had a significant effect on the performance of equity funds. The size of the equity fund and the maturity of the equity fund do not affect the performance of the equity fund. Based on the results, the Investment Manager as the investors' trusted party for managing their investment funds needs to pay attention to inflation to manage the assets properly. As an investor, it is required to pay attention to the investment policy in the fund fact sheet, prospectus, and strategy of each equity fund in order to make the right decision.
\end{abstract}

Keywords: Performance Equity Fund, Inflation, Equity Fund Size, Age Equity Fund

\section{PENDAHULUAN}

Dewasa ini perkembangan investasi di pasar modal semakin meningkat. Investasi menjadi sarana bagi pemilik modal (investor) untuk meningkatkan kekayaannya. Investor dapat memperoleh keuntungan dari sejumlah dana yang ditempatkannya pada instrument investasi tertentu. Di dalam investasi terdapat istilah high risk high return yang artinya setiap keuntungan yang besar disertai dengan risiko yang besar. Maka semakin tinggi return investasi akan semakin tinggi juga tingkat risiko yang dihadapi. Investasi yang benar dapat meningkatkan penghasilan dan memberikan kesejahteraan bagi para investor. Investasi tidak terbatas pada sektor rill yang membutuhkan modal besar, investasi juga dapat dilakukan dengan modal kecil, contohnya sebesar Rp 10,000,00. Investasi tersebut dapat dilakukan di reksa dana dengan tujuan mengatasi ketidakmampuan modal untuk berinvestasi dalam sektor rill. Reksa dana merupakan alternatif investasi bagi para investor yang memiliki keterbatasan waktu, pengetahuan, dan keahlian dalam memahami risiko-risiko investasi. Saat ini investasi dapat dilakukan mulai dari Rp 10.000,00, hal ini menyebabkan meningkatknya minat millennials sebagai investor muda terhadap pasar modal tanah air (Ramadhan, 2020). Adapun salah satu karakteristik generasi millennials adalah tertarik pada investasi yang memiliki fluktuasi tinggi seperti reksa dana berbasis saham (Irmayani, 2019). 
Seperti reksa dana lainnya, kinerja reksa dana saham dipengaruhi oleh faktor eksternal dan faktor internal. Adapun faktor eksternal yang dapat mempengaruhi kinerja reksa dana saham adalah inflasi sedangkan faktor internalnya meliputi ukuran reksa dana dan umur reksa dana (Utami \& Dharmastuti, 2014). Berdasarkan kondisi tersebut, penelitian ini bertujuan untuk mengetahui pengaruh Inflasi, Ukuran Reksa Dana, dan Umur Reksa Dana terhadap Kinerja Reksa Dana Saham Di Indonesia Periode Tahun 2010-2019.

\section{KAJIAN TEORI}

Berdasarkan Undang-undang Republik Indonesia No. 8 tahun 1995 tentang pasar modal, Bab IV tentang Reksadana, reksa dana merupakan wadah untuk mengumpulkan dana dari sejumlah investor lalu digabungkan dan diinvestasikan dalam portofolio efek oleh manajer investasi. Pozen (1998) mendefinisikan "a mutual fund is an investment company that pools money from shareholders and invests in a diversified of securities." Pada dasarnya reksa dana dibentuk untuk mengumpulkan dana masyarakat yang memiliki modal namun tidak memiliki banyak waktu untuk mengelola dananya serta adanya keterbatasan pengetahuan terkait investasi.

Reksa dana pertama kali dikenal di Eropa sebagai reksa dana tertutup yaitu di Negara Belgia pada tahun 1822. Setelah itu, reksa dana menyebar luas di Inggris dan Skotlandia dalam bentuk Unit Investment Trust, dan pada tahun 1920, reksa dana dikenal sebagai Mutual Fund di Amerika Serikat. Undang-Undang Nomor 8 Tahun 1995 tentang Pasar Modal menandakan masuknya reksa dana ke Indonesia. Reksa dana berbentuk perjanjian investasi bersama yang dibuat oleh notaris dan disetujui oleh perusahaan pengelola investasi dan bank kustodian (1995). KIK memiliki definisi kontrak atau perjanjian berupa manajer investasi dan bank kustodian yang mengikat satu sama lain serta memiliki wewenang dan tanggungjawab berdasarkan Undang - Undang Pasar Modal pasal 18 ayat 1 huruf $b$.
Tabel 1. Perkembangan Jumlah Reksa Dana Saham Periode 2013-2019

\begin{tabular}{ccc} 
Periode & $\begin{array}{c}\text { Jumlah } \\
\text { Reksa Dana } \\
\text { Saham }\end{array}$ & $\begin{array}{c}\text { Nilai Aktiva Bersih } \\
\text { (NAB/Rp Triliun) }\end{array}$ \\
\hline 2013 & 165 & 110.77 \\
2014 & 165 & 111.82 \\
2015 & 213 & 109.78 \\
2016 & 271 & 121.07 \\
2017 & 304 & 130.10 \\
2018 & 339 & 153.77 \\
2019 & 367 & 139.16
\end{tabular}

Sumber: Otoritas Jasa Keuangan (OJK), 2021

Faktor eksternal dapat menyebabkan penurunan jumlah nilai aktiva bersih reksa dana saham, contohnya, penurunan pada tahun 2008 karena subrime mortage Amerika Serikat (Shiller, 2013). Lalu pada tahun 2019 terjadi perang dagang antara negara China dan Amerika Serikat, akibatnya, nilai aktiva bersih reksa dana saham Indonesia turun menjadi Rp 14,6 triliun. (dapat dilihat pada tabel 1). Penurunan nilai aktiva bersih disebabkan oleh kekhawatiran para pemodal professional atas ketegangan kedua negara tersebut sehingga pemodal profesional menarik dananya di reksa dana saham untuk menghindari penurunan dari nilai aktiva bersih. Jika melihat dana kelolaan atau nilai aktiva bersih pada tabel 1, adanya anomali atas pertumbuhan nilai aktiva bersih disebabkan oleh faktor eksternal yaitu inflasi.

Pasaribu dan Dionysia (2014) menyatakan bahwa inflasi merupakan faktor utama yang harus dipertimbangkan manajer investasi ketika berinvestasi, terutama mempertimbangkan perkembangan nilai aktiva bersih reksa dana saham. Hasil penelitian ini menunjukkan bahwa inflasi berpengaruh negatif signifikan terhadap kinerja reksa dana saham. Berkebalikan dengan hasil temuan penelitian tersebut, penelitian Saputri dan Ismanto (2020) mengemukakan bahwa inflasi mempengaruhi kinerja reksa dana saham secara positif. Selain faktor eksternal, faktor internal seperti ukuran dan umur reksa dana saham juga dapat menyebabkan perubahan pada kinerja reksa dana saham.

Ukuran reksa dana saham menjadi pertimbangan manajer investasi dalam menilai kinerja reksa dana saham. Total nilai aktiva bersih 
(NAB) menentukan pula besar kecilnya reksa dana saham tersebut. Ukuran reksa dana saham mempengaruhi kinerja reksa dana saham, seperti fleksibilitasnya serta manfaat yang ditawarkan seperti pengurangan beban biaya investor. Besar kecilnya reksa dana saham mencerminkan besarnya dana yang dikelola oleh manajer investasi. Bagi para investor profesional besaran sebuah ukuran reksa dana saham selalu menjadi kriteria dalam sebuah keputusan dalam berinvestasi pada reksa dana saham dikarenakan apabila reksa dana saham memiliki ukuran yang besar maka akan memberikan keuntungan bagi investor seperti dari sisi beban biaya. Banyak penelitian terkait dengan investigasi ukuran reksa dana saham terhadap kinerja reksa dana saham. Menurut Asriwahyuni (2017), kinerja reksa dana saham dipengaruhi oleh ukuran reksadana saham secara positif. Hal ini berarti, semakin besar ukuran reksa dana saham maka semakin tinggi kinerja reksa dana saham tersebut. Akan tetapi, hal ini bertolak belakang dengan penelitian yang dilakukan oleh Dahlquist (2000) yang menyatakan bahwa fund size atau ukuran reksa dana saham tidak memiliki pengaruh positif terhadap kinerja reksa dana saham. Hal ini didukung dengan penelitian Saputri dan Ismanto (2020) yang mengatakan ukuran reksa dana tidak berpengaruh positif terhadap kinerja reksa dana. Dengan adanya gap analisis tersebut, maka perlu dilakukan penelitian kembali untuk memastikan apakah ukuran reksa dana saham dapat mempengaruhi kinerja reksa dana saham.

Umur reksa dana saham juga bisa sebagai cerminan pengalaman dari manajer investasi dalam mengelola reksa dana saham. Semakin besar umur reksa dana saham memperlihatkan semakin berpengalamannya manajer investasi dalam mengelola portofolio dibandingkan dengan reksa dana saham yang berumur lebih muda. Umur reksa dana saham yang lebih tua akan mempunyai track record lebih panjang, track record tersebut dapat dijadikan item untuk menilai performa manajer investasi dalam melakukan pengelolaannya. Penelitian yang dilakukan oleh Asriwahyuni (2017) mengatakan bahwa umur reksa dana saham tidak berpengaruh terhadap kinerja reksa dana saham. Sejalan dengan temuan tersebut, penelitian yang dilakukan Hermawan \& Wiagustini (2016) menyatakan hal yang sama. Akan tetapi, tidak selaras dengan penelitian yang dilakukan oleh Saurahman (2015) dan Kurniadi (2014) yang mengatakan bahwa adanya umur reksa dana saham berpengaruh positif terhadap kinerja reksa dana saham. Melihat gap analisis tersebut, maka menarik untuk diteliti kembali terkait pengaruh umur reksa dana saham terhadap kinerja reksa dana saham sehingga hasil penelitian lebih relevan untuk kondisi saat ini.

Identifikasi kinerja reksa dana saham dalam penelitian ini menggunakan reksa dana saham yang berkomposisi minimal $80 \%$ efek ekuitas dan minimal 20\% pasar uang atau obligasi. Reksa dana saham dipilih dikarenakan lebih berfluktuasi dari jenis reksa dana lainnya hal tersebut disebabkan sebagian besar portofolio ditempatkan dalam efek saham yang memiliki sifat fluktuatif (Hermawan, 2016). Reksa dana saham memiliki tantangan tersendiri sebagai pilihan investasi terutama bagi kalangan millennials yang menyukai investasi berfluktuatif. Reksa dana saham memiliki karakteristik high risk - high return dikarenakan melakukan penempatan pada saham - saham yang terdiversifikasi. Adapun baik buruknya dalam berinvestasi tidak terlepas dari faktor eksternal dan internal yang mempengaruhi kinerja reksa dana saham, faktor-faktor yang diduga mempunyai pengaruh terhadap kinerja reksa dana saham yaitu inflasi, ukuran reksa dana saham, dan umur reksa dana saham. Faktor-faktor tersebut secara teoritis sangat berhubungan dengan kinerja reksa dana saham sehingga diharapkan dapat menjadi pertimbangan bagi investor terutama untuk kalangan millennials dalam melakukan investasi pada reksa dana saham. Variabel dalam penelitian ini ialah inflasi, ukuran reksa dana saham, umur reksa dana saham terhadap kinerja reksa dana saham di Indonesia periode tahun 20102019.

Berdasarkan latar belakang tersebut maka dapat ditarik hipotesis, sebagai berikut:

$\mathrm{H}_{1}$ : Inflasi Berpengaruh Negatif terhadap Kinerja Reksa Dana Saham.

$\mathrm{H}_{2}$ : Ukuran Reksa Dana Saham Berpengaruh Positif terhadap Kinerja Reksa Dana Saham. 
$\mathrm{H}_{3}$ : Umur Reksa Dana Saham berpengaruh Positif terhadap Kinerja Reksa Dana Saham

\section{METODOLOGI}

Penelitian ini bersifat kuantitatif. Menurut Sugiyono (2013), penelitian kuantitatif berlandaskan pada filsafat positivisme, yang dilakukan untuk menguji hipotesis dengan sampel yang representatif.

Penelitian ini menggunakan data sekunder. Data tersebut berupa historis persentase tahunan masing-masing reksa dana saham periode 20102019 yang telah terdaftar di Otoritas Jasa Keuangan dan didapat dari website resmi Pasar Dana (PT Bina Investama Infonet, 2019) serta website resmi OJK (Otoritas Jasa Keuangan, 2017).

Populasi adalah suatu wilayah yang berisi objek atau subjek yang bersifat kuantitatif dan eksklusif yang dimaksudkan untuk diamati dan diselidiki dengan tujuan untuk menarik kesimpulan. Populasi yang dipilih dalam penelitian ini adalah reksa dana saham yang terdiri dari 367 reksa dana saham yang terdaftar di Otoritas Jasa Keuangan.

Penelitian ini menggunakan teknik purposive sampling yang artinya sampel dipilih menggunakan kriteria yang disesuaikan dengan penelitian. Teknik purposive sampling merupakan teknik pengambilan sampel melalui pertimbangan atau kriteria tertentu. Adapun kriteria sample dalam penelitian ini adalah sebagai berikut

a. Reksa dana saham yang terdaftar di Otoritas Jasa Keuangan periode 2010 - 2019, diharapkan menghasilkan sampel yang cukup dan dapat digeneralisasi.

b. Reksa dana saham yang tanggal efektifnya sudah 10 tahun, dikarenakan fenomena terjadi selama 10 tahunan.

c. Reksa dana saham yang memiliki jenis kategori konvensional.

d. Reksa dana saham yang menggunakan jenis denominasi IDR.
Kriteria tersebut diambil agar dapat memberikan keakuratan sampel pada penelitian ini. Berdasarkan kriteria di atas, terdapat 37 dari 367 reksa dana saham yang memenuhi kriteria tersebut dan akan dijadikan sampel dalam penelitian ini. Pada tabel 2 ditunjukkan detail seleksi sampel yang digunakan:

Tabel 2. Kriteria Pemilihan Sampel

\begin{tabular}{|c|l|c|}
\hline No & \multicolumn{1}{|c|}{ Keterangan } & Total \\
\hline 1 & $\begin{array}{l}\text { Reksa dana saham yang terdaftar di } \\
\text { Otoritas Jasa Keuangan periode 2010 - } \\
2019\end{array}$ & 367 \\
\hline 2 & $\begin{array}{l}\text { Reksa dana saham yang tanggal efektifnya } \\
<10 \text { tahun terakhir }\end{array}$ & -319 \\
\hline 3 & $\begin{array}{l}\text { Reksa dana saham di luar kategori } \\
\text { konvensional }\end{array}$ & -11 \\
\hline 4 & $\begin{array}{l}\text { Reksa dana saham yang bukan } \\
\text { menggunakan jenis denominasi IDR }\end{array}$ & $\mathbf{3 7}$ \\
\hline $\mathbf{5}$ & $\begin{array}{l}\text { Berdasarkan kriteria sampel tersebut } \\
\text { terdapat jumlah reksa dana saham } \\
\text { sebesar }\end{array}$ & 0 \\
\hline
\end{tabular}

sumber: data sekunder diolah 2021 (PT Bina Investama Infonet, 2019)

Berdasarkan kriteria pemilihan sampel, diketahui jumlah sampel dalam penelitian ini sebanyak 37 reksa dana saham. Adapun ke-37 reksa dana saham yang dimaksud ditunjukkan pada tabel 3.

Teknik pengolahan data menggunakan uji analisis regresi linier berganda yang bertujuan mengetahui hubungan antara dua variabel bebas atau lebih terhadap satu variabel terikat. Adapun persamaan regresi linier berganda ini dapat diformulasikan sebagai berikut:

$$
Y=\alpha+\beta 1 \times 1+\beta 2 X 2+\beta 3 X 3+e
$$

Keterangan :

$\mathrm{Y}$ : kinerja reksa dana saham

$\alpha$ : Konstanta

$\beta$ : slope atau koefisien regresi

$\mathrm{X}_{1}$ : Inflasi

$\mathrm{X}_{2}$ : ukuran reksa dana saham

$\mathrm{X}_{3}$ : umur reksa dana saham

e : Residual error 
Tabel 3. Sampel Reksa Dana Saham Periode 2010-2019

\begin{tabular}{|c|c|c|c|}
\hline No & Reksa Dana Saham & Manajer Investasi & $\begin{array}{c}\text { Tanggal } \\
\text { Diperdagang } \\
\text { kan }\end{array}$ \\
\hline 1 & ARCHITAS SAHAM DINAMIS & Architas Asset Management Indonesia, PT & 05-Aug-97 \\
\hline 2 & BAHANA DANA EKUITAS ANDALAN & Bahana TCW Investment Management, PT & 01-Dec-05 \\
\hline 3 & DANA EKUITAS PRIMA & Bahana TCW Investment Management, PT & 13-Feb-06 \\
\hline 4 & BAHANA DANA PRIMA & Bahana TCW Investment Management, PT & 08-Aug-96 \\
\hline 5 & BATAVIA DANA SAHAM OPTIMAL & Batavia Prosperindo Aset Manajemen, PT & 19-Oct-06 \\
\hline 6 & BATAVIA DANA SAHAM & Batavia Prosperindo Aset Manajemen, PT & 16-Dec-96 \\
\hline 7 & BNP PARIBAS PESONA & BNP Paribas Asset Management, PT & 10-Nov-97 \\
\hline 8 & BNP PARIBAS SOLARIS & BNP Paribas Asset Management, PT & 15-May-08 \\
\hline 9 & BNP PARIBAS EKUITAS & BNP Paribas Asset Management, PT & 28-Feb-01 \\
\hline 10 & BNP PARIBAS INFRASTRUKTUR PLUS & BNP Paribas Asset Management, PT & 15-Mar-07 \\
\hline 11 & RENCANA CERDAS & Ciptadana Asset Management, PT & 09-Jul-99 \\
\hline 12 & DANAREKSA MAWAR & Danareksa Investment Management, PT & 17-Jul-96 \\
\hline 13 & EMCO MANTAP & Emco Asset Management, PT & 11-Aug-05 \\
\hline 14 & EMCO GROWTH FUND & Emco Asset Management, PT & 11-Mar-08 \\
\hline 15 & FWD ASSET DIVIDEND YIELD EQUITY FUND & FWD Asset Management, PT & 18-Aug-05 \\
\hline 16 & FWD ASSET SECTORAL EQUITY FUND & FWD Asset Management, PT & 24-Dec-04 \\
\hline 17 & FWD ASSET VALUE SELECT EQUITY FUND & FWD Asset Management, PT & 10-Mar-08 \\
\hline 18 & REKSA DANA HPAM ULTIMA EKUITAS 1 & Henan Putihrai Asset Management, PT & 07-Dec-09 \\
\hline 19 & MANDIRI INVESTA ATRAKTIF & Mandiri Manajemen Investasi, PT & 30-Aug-05 \\
\hline 20 & MANDIRI INVESTA CERDAS BANGSA & Mandiri Manajemen Investasi, PT & 15-Jul-08 \\
\hline 21 & MANULIFE SAHAM ANDALAN & Manulife Aset Manajemen Indonesia, PT & 01-Nov-07 \\
\hline 22 & $\begin{array}{l}\text { REKSA DANA MANULIFE DANA SAHAM } \\
\text { KELAS A }\end{array}$ & Manulife Aset Manajemen Indonesia, PT & 01-Aug-03 \\
\hline 23 & MAYBANK DANA EKUITAS & Maybank Asset Management, PT & 23-Apr-07 \\
\hline 24 & MNC DANA EKUITAS & MNC Asset Management, PT & 01-Jul-08 \\
\hline 25 & PANIN DANA MAKSIMA & Panin Asset Management, PT & 01-Apr-97 \\
\hline 26 & PANIN DANA PRIMA & Panin Asset Management, PT & 27-Dec-07 \\
\hline 27 & PRATAMA SAHAM & Pratama Capital Assets Management, PT & 01-May-06 \\
\hline 28 & DANA PRATAMA EKUITAS & Pratama Capital Assets Management, PT & 12-Feb-04 \\
\hline 29 & PRINCIPAL TOTAL RETURN EQUITY FUND & Principal Asset Management, PT & 01-Jul-05 \\
\hline 30 & SCHRODER DANA PRESTASI & Schroder Investment Management Indonesia, PT & 29-May-97 \\
\hline 31 & SCHRODER INDO EQUITY FUND & Schroder Investment Management Indonesia, PT & 31-Aug-09 \\
\hline 32 & SCHRODER DANA ISTIMEWA & Schroder Investment Management Indonesia, PT & 27-Dec-04 \\
\hline 33 & SCHRODER DANA PRESTASI PLUS & Schroder Investment Management Indonesia, PT & 25-Sep-00 \\
\hline 34 & SIMAS DANAMAS SAHAM & Sinarmas Asset Management, PT & 05-Oct-07 \\
\hline 35 & SYAILENDRA EQUITY OPPORTUNITY FUND & Syailendra Capital, PT & 07-Jun-07 \\
\hline 36 & TRIM KAPITAL & Trimegah Asset Management, PT & 20-Mar-97 \\
\hline 37 & TRIM KAPITAL PLUS & Trimegah Asset Management, PT & 26-May-08 \\
\hline
\end{tabular}

Sumber: data sekunder diolah 2021 (PT Bina Investama Infonet, 2019)

Adapun data dalam penelitian ini merupakan data panel yang akan dianalisis menggunakan alat bantu yaitu software Eviews 9. Sebelum melakukan analisis regresi linier berganda, maka dilakukan terlebih dahulu estimasi parameter model yang hendak digunakan. Menurut Widarjono (2007) terdapat tiga model pendekatan dalam Eviews 9 yaitu Common Effect Model 
(CEM), Fixed Effect Model (FEM), Random Effect Model (REM). Dari tiga model yang diperkirakan, akan dipilih satu yang paling sesuai dengan tujuan penelitian. Terdapat level uji yang dapat digunakan sebagai alat untuk menentukan model regresi data panel (CEM, FEM, atau SEM) menurut ciri-ciri data yang dimiliki, yaitu Chow Test \& Hausman Test sebagai berikut:

\section{a. Uji Chow Test}

Uji Chow-Test bertujuan untuk menguji/membandingkan atau menentukan model mana yang terbaik apakah CEM atau FEM. Langkah-langkah yang dilakukan pada Uji Chow-Test adalah sebagai berikut:

- Bila nilai probability F dan Chi-square $>\alpha$ $=5 \%$, maka uji regresi panel data menggunakan CEM. Maka dilanjutkan ke Uji Lagrange Multiplier.

- Bila nilai probability F dan Chi-square $<\alpha$ $=5 \%$, maka uji regresi panel data menggunakan FEM. Maka dilanjutkan ke Uji Hausman.

\section{b. Uji Hausman Test}

Uji Hausman Test dilakukan untuk membandingkan atau menentukan model mana yang terbaik antara FEM atau REM. Langkah-langkah yang dilakukan pada Hausman Test sebagai berikut:

- Bila nilai probability F dan Chi-square $>\alpha$ $=5 \%$, maka uji regresi panel data menggunakan REM. Maka dilanjutkan ke Uji Lagrange Multiplier.

- Bila nilai probability F dan Chi-square $<\alpha$ $=5 \%$, maka uji regresi panel data menggunakan FEM.

c. Uji Lagrange Multiplier

Uji Lagrange Multiplier untuk membandingkan dan juga menentukan model terbaik antara CEM atau REM. Langkahlangkah yang dilakukan pada Lagrange Test sebagai berikut:

- Bila nilai both Breusch-Pagan $>\alpha=5 \%$, maka uji regresi panel data menggunakan CEM.
- Bila nilai both Breusch-Pagan $<\alpha=5 \%$, maka uji regresi panel data menggunakan REM.

Uji asumsi klasik dilakukan untuk menguji kualitas data sehingga data absah dan tidak bias. Uji asumsi klasik dibagi menjadi empat pengujian yang harus dipenuhi sebelum dilakukkan uji regresi linier berganda, adapun uji yang dimaksud adalah uji normalitas, uji heteroskedastisitas, uji multikolinearitas, uji autokorelasi.

\section{Operasionalisasi Variabel}

Penelitian ini terdiri dari 4 variabel yaitu, inflasi, ukuran reksa dana saham, dan umur reksa dana saham.

Tabel 4. Operasional Variabel

\begin{tabular}{|c|c|c|c|c|}
\hline No & Variabel & Definisi & Ukuran & Skala \\
\hline 1 & $\begin{array}{l}\text { Inflasi } \\
\left(\mathrm{X}_{1}\right)\end{array}$ & $\begin{array}{l}\text { Perbandingan } \\
\text { selisih return } \\
\text { dengan return } \\
\text { bebas risiko }\end{array}$ & $\begin{array}{l}\mathrm{CPI}_{\mathrm{t}} \\
=\frac{\mathrm{C}_{\mathrm{t}}}{\mathrm{C}_{0}} \times 100\end{array}$ & Rasio \\
\hline 2 & $\begin{array}{l}\text { Ukuran } \\
\text { Reksa } \\
\text { Dana } \\
\text { Saham } \\
\left(\mathrm{X}_{2}\right)\end{array}$ & $\begin{array}{l}\text { Total nilai aktiva } \\
\text { dikurangi total } \\
\text { kewajiban }\end{array}$ & $\begin{array}{c}\text { NAB= Total } \\
\text { Aktiva }- \\
\text { Kewajiban } \\
\text { Ukuran = Log } \\
\text { NAB }\end{array}$ & Rasio \\
\hline 3 & $\begin{array}{l}\text { Umur } \\
\text { Reksa } \\
\text { Dana } \\
\text { Saham } \\
\left(\mathrm{X}_{3}\right)\end{array}$ & $\begin{array}{l}\text { Suatu reksa dana } \\
\text { saham mulai } \\
\text { diperdagangkan }\end{array}$ & $\begin{array}{c}\text { Dihitung sejak } \\
\text { waktu efektif } \\
\text { diperdagangkan }\end{array}$ & Rasio \\
\hline 4 & $\begin{array}{l}\text { Kinerja } \\
\text { Reksa } \\
\text { Dana } \\
\text { Saham } \\
\text { (Y) }\end{array}$ & $\begin{array}{l}\text { Perbandingan } \\
\text { selisih capital } \\
\text { gain dengan } \\
\text { tingkat bebas } \\
\text { risiko } \\
\text { menggunakan } \\
\text { metode Sharpe } \\
\text { Ratio }\end{array}$ & $S p=\frac{\mathrm{Rp}-\mathrm{Rf}}{\Sigma \mathrm{p}}$ & Rasio \\
\hline
\end{tabular}

Sumber : Data sekunder diolah 2021

\section{HASIL PENELITIAN DAN PEMBAHASAN}

Dalam penelitian ini data yang digunakan merupakan data panel dengan jumlah objek penelitian sebanyak 37 reksa dana saham pada periode 2010-2019. Dalam menentukan model estimasi yang digunakan pada penelitian ini maka dilakukannya uji chow-test dengan menggunakan model FEM. Sebagai tahapan pertama apabila uji chow-test menunjukan hasil Chi-square $>\alpha=5 \%$, maka model CEM yang terpilih dapat dilanjutkan 
ke uji lagrange multiplier. Apabila pada uji chowtest menunjukan hasil Chi-square $<\alpha=5 \%$, maka model FEM yang terpilih dan dapat dilanjutkan ke uji hausman test.

Tabel 5. Hasil Uji Chow-Test

Redundant Fixed Effects Tests

Equation: MODEL_FEM

Test cross-section fixed effects

\begin{tabular}{lccc}
\hline \hline Effects Test & Statistic & d.f. & Prob. \\
\hline \hline $\begin{array}{l}\text { Cross-section F } \\
\text { Cross-section }\end{array}$ & 0,836025 & $(36.330)$ & 0,7377 \\
Chi-square & 32,293797 & 36 & 0,6456 \\
\hline \hline
\end{tabular}

Sumber: Hasil Eviews (Diolah)

Tabel 5 menunjukkan bahwa nilai probabilitas Cross-section Chi-square pada uji chow-test sebesar 0,6456>0,05 atau 5\%. Artinya dalam uji chow-test model CEM terpilih, maka dilanjutkan ke uji lagrange multiplier.

Tabel 6. Hasil Uji Lagrange Multiplier Lagrange Multiplier Tests for Random Effects Null hypotheses: No effects

Alternative hypotheses: Two-sided (Breusch-Pagan) and onesided (all others) alternatives

\begin{tabular}{cccc}
\hline \hline & \multicolumn{3}{c}{ Test Hypothesis } \\
& Cross-section & Time & Both \\
\hline \hline Breusch-Pagan & 5,457862 & 3365,538 & 3370,996 \\
& $(0,0195)$ & $(0,0000)$ & $(0,0000)$ \\
\multicolumn{3}{c}{ Sumber: Hasil Eviews (Diolah) }
\end{tabular}

Berdasarkan tabel 6 diperoleh bahwa nilai both Breusch-Pagan sebesar 0,00 <0,05 atau 5\%, artinya maka model terbaik yang dipilih untuk digunakan adalah model REM. Diketahui model estimasi data panel yang cocok untuk digunakan yaitu model REM (Random Effect Model). Selanjutnya untuk menghasilkan model estimasi regresi yang BLUE (Best Linier Unbiased Estimation) maka akan dilakukan uji asumsi klasik.

Hasil analisis deskriptif dari variabelvariabel yang digunakan meliputi Inflasi $\left(\mathrm{X}_{1}\right)$, Ukuran Reksa Dana Saham $\left(\mathrm{X}_{2}\right)$, dan Umur Reksa Dana Saham $\left(\mathrm{X}_{3}\right)$ Kinerja Reksa Dana Saham (Y) dapat dilihat pada tabel 7.
Tabel 7. Hasil Uji Statistik Deskriptif

\begin{tabular}{lcccc} 
& $\mathrm{Y}$ & $\mathrm{X} 1$ & $\mathrm{X} 2$ & $\mathrm{X} 3$ \\
\hline Mean & 7,664 & 4,653 & 1320,906 & 10,743 \\
\hline Median & 6,165 & 3,630 & 498,800 & 10,000 \\
\hline Maximum & 102,1 & 8,360 & 18352,46 & 23,000 \\
\hline Minimum & $-56,97$ & 2,590 & 8,630 & 1,000 \\
\hline Std. Dev. & 17,15 & 2,115 & 2419,605 & 5,227 \\
\hline Skewness & 0,631 & 0,868 & 3,959 & 0,405 \\
\hline Kurtosis & 5,714 & 1,967 & 21,729 & 2,386 \\
\hline \multicolumn{5}{c}{} \\
\hline Jarque-Bera & 138,0764 & 62,92154 & 6374,330 & 15,921 \\
\hline Probability & 0,000 & 0,000 & 0,000 & 0,000 \\
\hline \multicolumn{5}{c}{} \\
\hline Sum & 2835,540 & 1721,610 & 488735,2 & 3975,000 \\
\hline Sum Sq. Dev. & 108559,3 & 1650,363 & $2,16 \mathrm{E}+09$ & 10080,61 \\
\hline \multicolumn{5}{c}{} \\
\hline Observations & 370 & 370 \\
\hline \multicolumn{5}{c}{ Sumber: Hasil Eviews (Diolah) } \\
\hline
\end{tabular}

Berdasarkan tabel 7, data yang diobservasi sebanyak 370 data time series selama 10 tahun atau periode 2010-2019 dan jumlah reksa dana saham yang terdaftar di pasar dana dan OJK selama masa periode penelitian sebanyak 37 reksa dana saham. Hasil analisis deskriptif tabel 7 dijelaskan sebagai berikut:

1. Variabel $X_{1}$ memiliki nilai mean (rata-rata) sebesar 4,653 yang berarti rata-rata variabel $\mathrm{X} 1$ relatif rendah.

2. Variabel $\mathrm{X}_{2}$ memiliki nilai mean (rata-rata) sebesar 1.320.906 atau Rp1,3 Triliun, yang berarti dana kelolaan reksa dana saham cukup besar. Hal ini menunjukkan tingkat kepercayaan investor pada reksa dana saham cukup tinggi. Dengan tingginya dana kelolaan ini, reksa dana saham mampu memberikan pelayanan yang lebih baik serta dapat memberikan return terbaik.

3. Variabel $\mathrm{X}_{3}$ memiliki nilai mean (rata-rata) sebesar 10,74 atau 10 tahun. Nilai rata-rata ini menunjukan bahwa pengalaman manajer investasi reksa dana saham cukup baik dan sesuai dengan profil reksa dana saham yang memiliki jangka panjang sehingga manajer investasi cukup matang dalam mengelola portofolio pada reksa dana saham.

Uji normalitas bertujuan untuk melihat sebaran data yang diperoleh dari sebuah kelompok berdistribusi normal atau tidak. Model regresi yang baik dapat dilihat dari distribusi residual yang normal atau mendekati normal. penelitian ini melihat dari hasil nilai Probability, apabila pengujian data penelitian menghasilkan nilai 
Probability $>0,05$ atau bila nilai Jarque Bera (JB) $<2$ maka data berdistribusi normal.

Gambar 1. Hasil Uji Normalitas

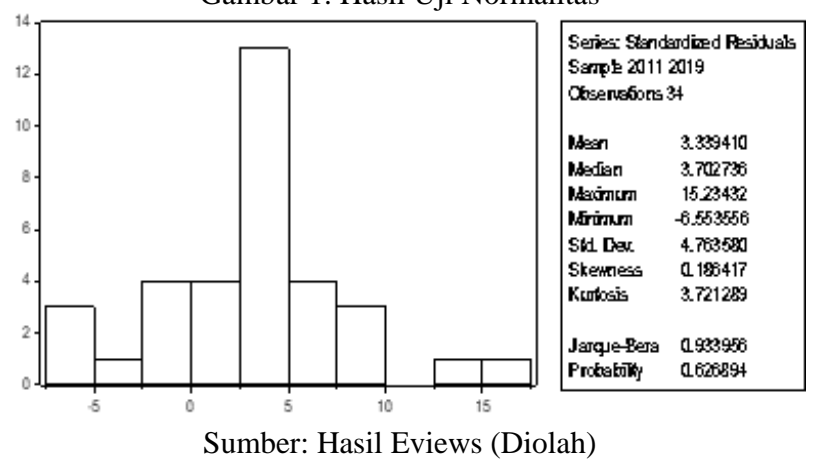

Berdasarkan gambar 1, terlihat bahwa nilai probability sebesar 0,626894 lebih besar dari 0,05 dan nilai JB sebesar 0,933956 lebih kecil dari 2. Artinya data residual data penelitian terdistribusi normal.

Uji heterokedastisitas dilakukan untuk melihat apakah terdapat ketidaksamaan variansi nilai residual pada variabel penelitian. Model regresi yang baik menunjukkan Homoskedastisitas yang berarti tidak terjadi Heteroskedastisitas (Gozhali, 2011). Artinya, tidak terdapat perbedaan dalam nilai residual variabel penelitian. Data dapat dikatakan terbebas dari masalah heteroskedastisitas apabila nilai Sum of Squared Residuals Ordinary Least Squares (SSR OLS) < Sum of Squared Residuals Generalized Least Square (SSR GLS). Untuk mengatasi masalah heterokedastisitas dapat dilakukannya transformasi data menggunakan metode GLS dengan Crosssection Weight (Sanjoyo, 2009).

Tabel 8. Model Random Effect

\begin{tabular}{lccc}
\hline \hline \multicolumn{3}{c}{ Weighted Statistics } \\
\hline \hline $\begin{array}{l}\text { R-squared } \\
\text { Adjusted R- }\end{array}$ & 0,231285 & Mean dependent var & 0,002156 \\
squared & 0,224967 & S.D. dependent var & 1,000497 \\
$\begin{array}{l}\text { S.E. of } \\
\text { regression }\end{array}$ & 0,880797 & Sum squared resid & 283,1680 \\
$\begin{array}{l}\text { F-statistic } \\
\text { Prob(F-statistic) }\end{array}$ & 0,000000 & & \\
\hline \hline
\end{tabular}

Sumber: Hasil Eviews (Diolah)

Berdasarkan hasil dari tabel 8 menunjukan bahwa nilai sum squared resid pada model random effect sebesar 283,1680 lebih kecil dari nilai sum squared resid pada model GLS-GMM Cross-
Section Weight sebesar 283,4156 di tabel 9 Artinya bahwa data penelitian homoskedastisitas dan terbebas dari masalah heterokedatisitas.

Tabel 9. Model GLS-GMM Cross-Section Weight

\begin{tabular}{lrll}
\hline \hline $\begin{array}{l}\text { R-squared } \\
\text { Adjusted R- }\end{array}$ & 0,230613 & Mean dependent var & 0,002156 \\
$\begin{array}{l}\text { squared } \\
\begin{array}{l}\text { S.E. of } \\
\text { regression }\end{array}\end{array}$ & 0,224290 & S.D. dependent var & 1,000497 \\
$\begin{array}{l}\text { Durbin-Watson } \\
\text { stat }\end{array}$ & 2,322888 & J-statistic & 283,4156 \\
\begin{tabular}{l} 
Instrument rank \\
\hline \hline
\end{tabular} & 5 & Prob(J-statistic) & 0,000000 \\
\hline
\end{tabular}

Sumber: Hasil Eviews (Diolah)

Uji Multikolinearitas bertujuan untuk menguji dalam model regresi apakah ada ditemukan korelasi yang kuat antar variabelvariabel bebas (Gozhali, 2011). Model regresi yang baik seharusnya tidak terdapat korelasi antar variabel bebas dalam penelitian variabel. Gejala multikolinieritas diuji dengan menggunakan matrik korelasi antar variabel bebas. Apabila variable bebas memiliki korelasi yang cukup tinggi yakni diatas 0,90, dapat diindikasikan bahwa terjadi multikolinieritas.

\begin{tabular}{cccr}
\multicolumn{4}{c}{ Tabel 10. Hasil Uji Multikolinearitas-Correlation } \\
& X1 & X2 & X3 \\
\hline \hline X1 & 1,000000 & 0,016027 & $-0,291506$ \\
X2 & 0,016027 & 1,000000 & 0,211453 \\
X3 & $-0,291506$ & 0,211453 & 1,000000 \\
& Sumber: Hasil Eviews (Diolah) &
\end{tabular}

Berdasarkan tabel 10 terlihat bahwa hubungan antara setiap variabel independen $\mathrm{X}_{1}, \mathrm{X}_{2}$, dan $\mathrm{X}_{3}$ memiliki nilai lebih rendah dari 0,90 , yang berarti tidak terjadi multikolinieritas pada model regresi penelitian ini.

Uji autokorelasi bertujuan untuk melihat apakah terdapat suatu korelasi antar periode A dengan periode sebelumnya. Uji autokorelasi dilakukan pada data runtutan waktu, biasanya data yang lebih dari 1 tahun memerlukan pengujian data autokolerasi. Penelitian ini menggunakan uji durbin-watson. Adapun uji durbin-watson dilakukan dengan membandingkan nilai durbinwatson hitung (d) dengan nilai durbin-watson tabel, yaitu batas atas $\left(\mathrm{d}_{\mathrm{u}}\right)$ dan batas bawah $\left(\mathrm{d}_{\mathrm{L}}\right)$.

Berdasarkan hasil uji autokorelasi DurbinWatson pada tabel 8 menjelaskan bahwa hasil uji 
DW sebesar 2,310431. Dengan menggunakan alpha $5 \%,(\mathrm{k}: \mathrm{N})=(3: 37)$, maka nilai $\left(\mathrm{d}_{\mathrm{u}}: 4-\mathrm{d}_{\mathrm{U}}\right)=$ $(1,655: 2,345)$. Sehingga hasil uji autokorelasinya adalah $\mathrm{d}_{\mathrm{U}}<\mathrm{DW}<4-\mathrm{d}_{\mathrm{U}}$ yaitu $\mathrm{d}_{\mathrm{u}} 1,655<$ uji DW $2,310431<\mathrm{d}_{\mathrm{U}} 2,345$, hasil dari uji autokorelasi menandakan bahwa model regresi tidak terdapat masalah autokorelasi.

Analisis uji $\mathrm{F}$ ini mempunyai tujuan utama yaitu untuk menguji adanya kesesuaian model regresi dalam penelitian yang dilakukan. Dalam penelitian ini, analisis uji $\mathrm{F}$ dilakukan untuk mengukur kesesuaian model regresi inflasi, ukuran reksa dana saham, dan umur reksa dana saham terhadap kinerja reksa dana saham. Kriteria pengambilan keputusan dalam analisis uji $\mathrm{F}$ ini menggunakan pendekatan $\mathrm{F}_{\text {statistic }}$ dibandingkan nilai $\mathrm{F}_{\text {critical value }}$ dengan taraf sig $5 \%$, berdasarkan statistical tabel nillai $\mathrm{F}_{\text {critical value diketahui sebesar }}$ 2,92. Berdasarkan hasil uji $\mathrm{F}$ pada tabel 8 , dapat disimpulkan bahwa nilai $\mathrm{F}_{\text {statistic }}$ sebesar 36,60618 $>F_{\text {critical value sebesar 2,92. Artinya model regresi }}$ memberikan hasil yang signifikan, sehingga dapat disimpulkan bahwa Inflasi, Ukuran Reksa Dana dan Umur Reksa Dana secara simultan mempunyai pengaruh yang signifikan terhadap kinerja reksa dana saham, maka dapat disimpulkan $\mathrm{H}_{0}$ diterima dan variabel independen secara signifikan berpengaruh terhadap variabel dependen.

Analisis uji $t$ ini mempunyai tujuan utama yaitu untuk melihat pengaruh yang dimiliki masing-masing variabel $\mathrm{X}$ dalam penelitian yaitu inflasi, ukuran reksa dana saham, dan umur reksa dana saham terhadap variabel $\mathrm{Y}$ penelitian atau kinerja reksa dana saham.

Tabel 11. Hasil Uji t (Uji Parsial)

\begin{tabular}{crrrr}
\hline \hline Variable & Coefficient & Std. Error & t-Statistic & Prob. \\
\hline \hline C & 0,002342 & 0,046274 & 0,050603 & 0,9597 \\
ZX1 & 0,450978 & 0,048562 & 9,286639 & 0,0000 \\
ZX2 & 0,038777 & 0,047518 & 0,816039 & 0,4150 \\
ZX3 & $-0,080267$ & 0,049679 & $-1,615699$ & 0,1070 \\
\hline \hline
\end{tabular}

Sumber: Hasil Eviews (Diolah)

Tabel 11 menunjukkan bahwa tidak semua variabel bebas mempengaruhi variabel terikat secara signifikan. Berikut penjelasannya:

1. Inflasi terhadap Kinerja Reksa Dana Saham

Nilai coefficient inflasi sebesar 0,450978 dengan nilai prob. $0,000<\alpha 0,05$ yang berarti diterima $\mathrm{H}_{0}$. Berdasarkan hasil dari pengujian ini maka dapat disimpulkan bahwa variabel inflasi berpengaruh signifikan terhadap reksa dana saham dan memiliki pengaruh positif terhadap variabel terikatnya. Maka dapat disimpulkan bahwa inflasi berpengaruh signifikan positif terhadap kinerja reksa dana saham. Hal ini disebabkan karena inflasi yang terkontrol dengan stabil selama 4 tahun terakhir. Hasil penelitian ini sejalan dengan penelitian yang dilakukan oleh (Hermawan, 2016) yang menyatakan inflasi berpengaruh terhadap kinerja reksa dana saham. Akan tetapi pada penelitian ini inflasi memiliki pengaruh yang positif sehingga dapat mendorong pengembalian minimum atas investasi dalam jangka panjang. Sejalan dengan tujuan investasi dari reksa dana saham itu sendiri, apabila melihat data rata-rata kinerja reksa dana saham (Y) pada tabel 7 sebesar 7,66\% lebih tinggi dari nilai rata-rata inflasinya (X1) sebesar 4,64\%. Hal tersebut dapat menjelaskan selama 10 tahun terakhir kinerja reksa dana saham didorong oleh pertumbuhan dari inflasi yang stabil terjaga. Oleh karena itu, berinvestasi pada reksa dana saham sangat menjadi pilihan yang tepat terutama bagi kalangan millennials yang saat ini sedang ingin berinvestasi dalam jangka panjang. Investasi jangka panjang yang baik berupa melakukan penempatan investasi dengan jangka waktu 1020 tahun yang nantinya dapat dinikmati ketika masa pensiun telah tiba.

2. Ukuran Reksa Dana Saham terhadap Kinerja Reksa Dana Saham

Nilai coefficient ukuran reksa dana saham sebesar 0,038777 dengan nilai prob. 0,4150 > $\alpha 0,05$ yang berarti ditolak $\mathrm{H}_{0}$. Artinya hasil dari pengujian ini dapat disimpulkan bahwa variabel ukuran reksa dana saham tidak berpengaruh signifikan terhadap kinerja reksa dana saham serta memiliki pengaruh positif. Artinya penelitian pada variabel ini belum memiliki cukup bukti untuk menjelaskan pengaruh ukuran reksa dana saham terhadap kinerja reksa dana saham. Umumnya bagi para investor profesional besaran sebuah ukuran reksa dana saham selalu menjadi kriteria dalam 
sebuah keputusan dalam berinvestasi, dikarenakan ukuran yang besar maka akan memberikan keuntungan baik investor tersebut dari sisi beban biayanya. Akan tetapi pada penelitian ini ukuran reksa dana tidak berpengaruh signifikan terhadap kinerja reksa dana saham, ini berarti besar kecilnya ukuran reksa dana saham tidak berdampak pada perubahan kinerja reksa dana saham, serta ukuran tidak dapat dijadikan acuan bagi investor terutama kalangan millennials.

3. Umur Reksa Dana Saham terhadap Kinerja Reksa Dana Saham

Nilai coefficient umur reksa dana saham sebesar -0,080267 dengan nilai prob. 0,1070 > a 0,05 yang berarti ditolak $\mathrm{H}_{0}$. Berdasarkan hasil dari pengujian ini maka dapat disimpulkan bahwa variabel umur reksa dana saham tidak berpengaruh signifikan terhadap kinerja reksa dana saham serta memiliki pengaruh negatif. Artinya penelitian pada variabel ini belum memiliki cukup bukti untuk menjelaskan pengaruh umur reksa dana saham terhadap kinerja reksa dana saham. Hasil penelitian ini sejalan dengan penelitian terdahulu yang dilakukan oleh (Saputri, 2020) mengatakan umur reksa dana saham tidak berpengaruh terhadap kinerja reksa dana saham. Pada umumnya reksa dana saham dengan umur yang lebih lama akan memiliki track record yang lebih panjang, tetapi tidak dapat memberikan gambaran kinerja yang lebih baik kepada investor. Umumnya track record tersebut dapat dijadikan item untuk menilai performa manajer investasi dalam melakukan pengelolaannya reksa dana sahamnya.

Uji koefisien determinasi ( $\mathrm{R}$ Square) dilakukan untuk mengetahui besarnya pengaruh kemampuan variabel independen untuk menjelaskan variabel dependen. Hasil pengujian koefisien determinasi melalui Eviews9 dapat dilihat pada tabel 8 . Berdasarkan tabel 8 , dapat dilihat bahwa nilai Adjusted $R$ square sebesar 0,224967 dapat ditarik kesimpulan bahwa sebesar $22,49 \%$ variabel dependen dapat dijelaskan oleh variabel independennya. Sedangkan sisanya, yaitu sebesar $77,51 \%$ dapat dijelaskan oleh variabel lainnya diluar model regresi penelitian. Hal tersebut menandakan keterbatasan kemampuan variabel independen dalam menjelaskan variabel dependen.

\section{KESIMPULAN}

Inflasi mempengaruhi kinerja reksa dana saham secara positif signifikan pada periode tahun 2010-2019, artinya inflasi dapat menjelaskan kinerja reksa dana saham di Indonesia periode tahun 2010-2019.

Ukuran reksa dana saham tidak mempengaruhi kinerja reksa dana saham secara signifikan pada periode tahun 2010-2019 serta memiliki pengaruh positif yang artinya ukuran reksa dana saham tidak memiliki kemampuan untuk memprediksi kinerja reksa dana saham di Indonesia periode tahun 2010-2019.

Umur reksa dana saham tidak mempengaruhi kinerja reksa dana saham di Indonesia pada periode tahun 2010-2019 serta memiliki pengaruh negatif, artinya umur reksa dana saham tidak memiliki kemampuan untuk memprediksi kinerja reksa dana saham di Indonesia periode tahun 2010-2019.

Manajer investasi, sebagai pihak yang dipercaya oleh para investor dalam mengelola dana investasinya, perlu mengelola dana investor dengan timming yang tepat sehingga dapat memperoleh return yang diharapkan. Hal ini menjadi penting sebagaimana yang diketahui dari hasil penelitian ini bahwa inflasi yang memiliki pengaruh signifikan terhadap kinerja reksa dana saham. Kehati-hatian dalam melakukan penempatan portofolio pada reksa dana saham wajib dimiliki oleh manajer investasi agar kinerja reksa dana saham tetap terjaga dan sesuai dengan ekspetasi return yang diharapkan oleh investor. Penelitian ini dapat menjadi bahan pertimbangan bagi manajer investasi untuk memperbaiki performa dan kinerjanya dalam mengelola portofolio reksa dana saham ketika inflasi terjadi.

Investor perlu mengingat bahwa inflasi, ukuran reksa dana, dan umur reksa dana memiliki pengaruh yang signifikan secara simultan terhadap kinerja reksa dana saham. Oleh karena itu investor harus memperhatikan kebijakan investasi yang berada di dalam fund fact sheet, prospectus, dan 
strategi masing-masing reksa dana saham yang ingin diinvestasikan sehingga dapat mengambil keputusan yang tepat sebelum melakukan investasi pada reksa dana saham. Calon investor juga sebaiknya memperhatikan tingkat pertumbuhan inflasi dikarenakan inflasi memiliki pengaruh yang signifikan terhadap kinerja reksa dana saham. Investor juga dapat melihat beberapa indikator lain seperti turnover ratio dan expense ratio tiap reksa dana saham guna untuk sebagai bahan pertimbangan dalam mengambil keputusan investasi.

Penelitian selanjutnya dapat mengganti variabel atau menggunakan variabel lainnya yang memiliki pengaruh terhadap kinerja reksa dana saham juga dapat menggunakan data per kuartal atau periode penelitian yang terbaru sehingga hasil peneltian dapat menghasilkan informasi yang lebih akurat dan relevan. Di samping itu, penelitian berikutnya juga dapat mengganti sampel penelitian dengan reksa dana saham indexing seperti Reksa Dana Saham Indeks LQ45, Reksa Dana Saham Indeks IDX30, dan lain sebagainya.

\section{DAFTAR PUSTAKA}

Asriwahyuni. (2017). Pengaruh ukuran dan umur pada kinerja reksa dana saham di Indonesia. E-Jurnal Akuntansi Universitas Udayana.

Dahlquist, M. E. (2000). Performance and Characteristics of Swedish Mutual Fund. Journal of Finance and Quantitative Analysis.

Gozhali. (2011). Aplikasi Analisis Multivariate dengan program IBM SPSS19. Semarang: Badan Penerbit Universitas Diponegoro, Edisi 5.

Hermawan, D. d. (2016). Pengaruh Inflasi, Suku Bunga, Ukuran Reksa Dana, dan Umur Reksa dana Terhadap Kinerja Reksa Dana. E-Journal Manajemen Unud.

Irmayani, I. (2019, Oktober 25). Generasi Milenial dan Gaya Investasinya. Retrieved from disdukcapil.pontianak:

https://disdukcapil.pontianakkota.go.id/ge nerasi-milenial-dan-gaya-investasinyaditulis-oleh-irni-irmayani
Kurniadi. (2014). Analisis Fund Size, Expense Ratio, Turnover Ratio, Fund Age, dan Cash Flow Terhadap Kinerja Reksa Dana Saham di Indonesia (Periode 2010-2012). Skripsi Fakultas Ekonomika dan Bisnis Universitas Diponegoro, Semarang.

Otoritas Jasa Keuangan. (2017). OJK. Retrieved from OJK: www.ojk.go.id

Pasaribu, d. D. (2014). Pengaruh Suku Bunga SBI, Tingkat inflasi, IHSG, dan Bursa Asing Terhadap Tingkat Pengembalian Reksa Dana Saham. Jurnal Akuntansi dan Manajemen.

Pozen. (1998). The Mutual Fund Business. Cambridge: MIT Press.

PT Bina Investama Infonet. (2019). Pasardana. Retrieved 2021, from Pasardana: www.pasardana.id

Ramadhan, T. (2020, April 25). Millenials pilih reksa dana sebagai instrumen investasi masa depan. Retrieved from Marketeers: https://marketeers.com/millenial-pilihreksa-dana-sebagai-instrumen-investasimasa-depan/

Sakti, I. (2018). ANALISIS REGRESI DATA PANEL MENGGUNAKAN EVIEWS. Skripsi Fakultas Ekonomi dan Bisnis Universitas Esa Unggul. Jakarta.

Sanjoyo. (2009, Mei 26). Langkah2 Model Panel Data. Retrieved from World Wide Web: https://forumekonometrika.blogspot.com/2009/05/lang kah2-model-panel-data.html

Saputri, d. I. (2020). Pengaruh Inflasi, Suku Bunga, Ukuran Reksa Dana dan Umur Reksa Dana Terhadap Kinerja Reksa Dana Tahun 2014-2018. Jurnal Sains Sosio Huaniora.

Saurahman. (2015). Analisis Pengaruh Pemilihan Sekuritas, Market Timing, Tingkat Risiko, Umur Reksa Dana dan Ukuran Reksa Dana Terhadap Kinerja Reksa Dana Campuran Berbentuk Kontrak Investasi Kolektif. Skripsi UIN Syarif Hidayatullah, Jakarta.

Shiller, J. (2013). The Subprime Solution. Princeton: Princeton University Press.

Sugiyono. (2013). Metode Penelitian Bisnis. Alfabeta. Bandung. 
Undang-undang Republik Indonesia No. 8 tahun 1995 tentang pasar modal, Bab IV tentang Reksadana, 10 November 1995 (Lembaran Negara Republik Indonesia Tahun 1995 Nomor 64, Tambahan Lembaran Negara Republik Indonesia Nomor 3608 1995). Retrieved from https://www.ojk.go.id/id/kanal/pasarmodal/regulasi/undangundang/Documents/Pages/undangundang-nomor-8-tahun-1995-tentangpasarmodal/UU\%20Nomor\%208\%20Tahun\%2 01995\%20(official).pdf

Utami, M., \& Dharmastuti, C. (2014). Faktor Eksternal dan Internal yang Mempengaruhi Return Investasi Produk Reksa Dana Campuran di Indonesia. Media Ekonomi dan Manajemen, 29(2).

Widarjono, A. (2007). Ekonometrika: Teori dan Aplikasi untuk Ekonomi dan Bisnis. Edisi Kedua. Yogyakarta: Ekonisia FE Universitas Islam Indonesia. 